what the editors see as a serious imbalance.

The book begins with an essay by Cora Diamond on John Stuart Mill, whom Diamond regards as a non-consequentialist writer in view of his interest in agent-relative factors and in the "tendencies" of actions. In some ways this is an unfortunate choice for an opening chapter: while interesting in content, it is, of all the chapters, the least accessible in style. The chapter is, however, immediately followed by a lively and provocative essay by Nicholas Denyer on the much maligned theory of "absolutism". Denyer draws out some of the more bizarre implications of consequentialism and introduces distinctions needed by non-consequentialist theories between intention and foresight on the one hand, and causing and allowing on the other. He makes the point that while moral absolutism enjoins us to choose "a good" alternative, within moral limits, consequentialism makes the impossible demand that we choose "the best" alternative from an indefinite number of candidates.

Denyer's chapter is followed by three chapters on the moral status of human and non-human animals. Stephen Clark and Tim Chappell take a strong line - some would say, too strong - with regard to respect for the flourishing of non-human animals according to the kind of being they are. Brian Scarlett argues that Peter Singer's view of the status of different kinds of being is, in fact, close to the view held by most of us, except where the concept of "person" is (unhelpfully, in Scarlett's view) brought into play.

Grant Gillett's chapter on the moral status of infants looks at metaphysical and relational factors neglected by consequentialists. Gillett sees a difficulty in approaching the question of child abuse from the perspective of preference utilitarianism: if an infant's value is assigned by the parents, in view of the fact that infants have no desire to live, it may be worse to frustrate the desires of abusive parents by punishment or censure than to kill the child who has, for them, a negative value.

John Cottingham and Lance Simmons, in the following two chapters, look at health as the goal of (or a good internal to) medicine. Can anything count as good medicine - for example, removing the breast of a professional golfer to improve her swing? Cottingham argues that health is the telos of medicine, that there is such a thing as a healthy member of the human kind, and that what amounts to medical treatment cannot be reinvented at will. Simmons looks at health from the angle of the virtues of the doctor: health is, if not the primary end of medicine, at least a good internal to medicine; to remove a normal breast is, at present, regarded by good doctors as a paramount attack on health and therefore incompatible with the virtues medicine requires.

A highlight of the book is a chapter by J L A Garcia on the part played by intention in the identification and evaluation of human acts. Garcia distinguishes between what we must intend to promote our goals and what we are likely to intend to promote our goals: we are likely, for example, to intend more than we strictly need so as to ensure that our goals are met. While an action which is not wrong because of what is intended may still be wrong for some other reason, intentions are none the less important in forming the "contents of the heart".

A chapter by Janet Smith looks at the principle of respect for autonomy, which is often found in conjunction both with consequentialism and with moral scepticism. The penultimate chapter by Jacqueline Laing consists of a critique of the work of Singer in particular. Laing makes a number of valuable points, although she is perhaps occasionally too severe. While not, it must be said, a writer of any great consistency, Singer may not be contradicting himself at quite every point which Laing suggests. Laing is, however, entirely justified in emphasising the "practical" aspect of Singer's views: they are not mere theory but have real-life implications for the treatment of flesh-and-blood human beings.

The final chapter, by Laing's coeditor David Oderberg, looks at the right to life as a right which, he argues, cannot be alienated by the subject. Oderberg maintains that even consequentialism recognises at least one inalienable right: the right to maximise utility. With regard to the alienability of rights in general, he observes that we are reluctant to mutilate people or to help them develop addictions, even at their own request. Moreover, we do not, in practice, see the right to life as something the subject can simply alienate: euthanasia is not proposed, even by those who propose it, for all who may request it.
As the editors point out in their introduction, Human Lives is far from homogeneous in content, containing $\underset{\vec{f}}{\vec{f}}$ quite diverse, though interlocking $\overline{\bar{\kappa}}$. approaches to bioethics. Not all the chapters are of equal value; all, how- $\overrightarrow{\overline{\vec{\omega}}}$ ever, are helpful to some degree. The book as a whole is an unusually rich read; a welcome contribution to the $\frac{\bar{\sigma}}{\bar{c}}$ somewhat meagre fare supplied by mainstream bioethics. Both those whoe are happy and those who are unhappy@્心 with dominant approaches to bioethics should read it with some. care.

HELEN WATT

The Linacre Centre,

London NW8ד

\section{Death, Dying and Residential Care}

Yvonne Shemmings, Aldershot, Hants, Avebury, Ashgate Publishing Ltd, 1996, 116 pages, $£ 30$.

This book reports a qualitative study $\overrightarrow{0}$ of 20 staff members working in residential homes caring for older peopte. Its declared aim was to understando the experiences of carers, most $8 \mathrm{f}$ them care assistants, during the latero stages of life of the residents. Although the author appears somewhat defensive about her choice of research method, this seemed totally appropriate for her purpose. In fact, the qualitative research approach has now gained sufficient academic credibility to make defensiveness unnecessary.

The study highlights the need to acknowledge the ethical and professional problems of carers in their rela-윽 tionships with the residents who have a brief life prospect. It appeared that dying and death, in spite of their inevitability, were treated as taboo음 topics not to be discussed. When death occurred attempts were made tour conceal it from the other residents. $N$ The poignancy of the emotions? expressed by care staff demonstrated their tensions and conflicts.

Although this is a small study frome which no generalisability can be or is claimed, the book deserves to be reaf? not only by students of the subject area but, most importantly, byō managers of residential homes forD elderly people.

Visiting Professor in Nursing Research 1/2 Silverknowes Road, Edinburgh EH4 5NX 